Review Article

\title{
Using next generation sequencing to tackle non-typhoidal Salmonella infections
}

\author{
John Wain ${ }^{1}$, Karen H Keddy ${ }^{2}$, Rene S. Hendriksen ${ }^{3}$, Salvatore Rubino ${ }^{4}$ \\ ${ }^{1}$ Norwich Medical School, University of East Anglia, Norwich, UK \\ ${ }^{2}$ Centre for Enteric Diseases, National Institute for Communicable Diseases of the National Health Laboratory \\ Service and Faculty of Health Sciences, University of the Witwatersrand, Johannesburg, South Africa \\ ${ }^{3}$ WHO Collaborating Centre for antimicrobial resistance in foodborne pathogens and European Union Reference \\ Laboratory for Antimicrobial Resistance, National Food Institute, Technical University of Denmark, Kgs. Lyngby, \\ Denmark \\ ${ }^{4}$ Department of Biomedical Science, Center for Biotechnology Development and Biodiversity Research, University \\ of Sassari, Sassari, Italy
}

\begin{abstract}
The publication of studies using next generation sequencing to analyse large numbers of bacterial isolates from global epidemics is transforming microbiology, epidemiology and public health. The emergence of multidrug resistant Salmonella Typhimurium ST313 is one example. While the epidemiology in Africa appears to be human-to-human spread and the association with invasive disease almost absolute, more needs to be done to exclude the possibility of animal reservoirs and to transfer the ability to track all Salmonella infections to the laboratories in the front line. In this mini-review we summarise what is currently known about non-typhoidal Salmonella in sub-Saharan Africa and discuss some of the issues which remain.
\end{abstract}

Key words: Salmonella Typhimurium ST313; non-typhoidal Salmonella; next generation sequencing

J Infect Dev Ctries 2013; 7(1):001-005.

(Received 15 October 2012 - Accepted 06 December 2012)

Copyright (C) 2012 Wain et al. This is an open-access article distributed under the Creative Commons Attribution License, which permits unrestricted use, distribution, and reproduction in any medium, provided the original work is properly cited.

\section{Introduction}

Background to the increase in non-typhoidal

Salmonella

In an unknown number of sub-Saharan African countries there is an increasing number of cases of multidrug resistant (MDR) non-typhoidal Salmonella (NTS) infection [1]. Previous authors highlight risk factors including human immunodeficiency virus (HIV) infection, extreme youth, malnutrition and malaria [2]. The greatest contributor to disease burden over the past decade is undoubtedly the increase in HIV-NTS co-infection $[3,4,5,6]$ associated with a very high mortality $[7,8]$. The first report of NTS in an acquired immune deficiency syndrome (AIDS) patient was from Haiti in 1983 [9] and five case reports from New York, United States of America (USA,) all with $S$. Typhimurium, were reported in 1985 [10]. Since then the impact of HIV on the cause of invasive salmonellosis has been dramatic: In one hospital in Ho Chi Minh City, Viet Nam, positive blood cultures for $S$. Typhi dropped from hundreds per year in the 1990 s to tens in the 2000s with an associated increase in NTS and Penicillium marneffei as the most common blood culture isolate [11]. Similarly, the increasing impact and differing epidemiology of NTS, compared with $S$. Typhi, is noted in several Africa countries [12] where NTS infection is expanding but the epidemiology has proved elusive. A systematic review of the literature suggests that NTS are responsible for nearly $60 \%$ of bloodstream infections due to Salmonella; NTS are now more common than enteric Salmonella [13]. In Zimbabwe, drug resistant invasive NTS infection was recognised as an increasing problem in the early nineties; between 1994 and 1996, 301 Salmonella were isolated from blood: $37.2 \%$ group D, $21.6 \%$ group B (possibly Salmonella Typhimurium) and $12.0 \%$ group C [14]. Although the HIV status of the patients was not tested, it seems likely that this was the beginning of the HIV-associated increase in NTS in Africa. 
Resistance to antibiotics and the emergence of sequence type 131

Multidrug resistance in NTS has remained a challenge after the turn of this century, including resistance to extended spectrum beta-lactam agents [15] and emerging resistance to the quinolones [16]. The sub-types, or strains, of NTS associated with invasive salmonellosis were described in Kenya as "multiclonal" in the late nineties [17], and in Malawi as showing considerable "inter-individual heterogeneity" during the same time period [8]. Yet analyses of recent isolates, using the power of new sequencing technologies, has shown the emergence of a single group of $S$. Typhimurium sequence type 313 (ST313). It seems from a soup of Salmonella serotypes and sub-types that one sub-type, $S$. Typhimurium ST313, has swept through the human population in both Malawi [18] and Kenya [19].

The genome sequencing of a broad collection of African isolates now shows that $S$. Typhimurium ST313 is a clonal group of bacteria (sharing common ancestry) which has been circulating for around 50 years and has now split into two lineages that have acquired similar resistance genes on separate occasions [20]. The microevolution of virulence gene expression has been associated with environmental stress [21] and it is possible that in sub-Saharan African countries extreme draught followed by rain storms, and hot days followed by cool nights, could have resulted it the emergence of a successful clone of $S$. Typhimurium. The genome data also show that several genes have been switched off by mutation or deletion of key genetic sequence thus creating "pseudogenes". The presence of pseudogenes is the hallmark of genome degradation caused by niche specialisation, in this case most likely host adaptation. The process is well described in other human adapted enteric Salmonella such as $S$. Typhi and S. Paratyphi A and has occurred over an evolutionary time scale [22]. Therefore, either $S$. Typhimurium ST313 has been associated with humans for millennia, or more likely, it has emerged from a pathogen which was already adapted to an animal host, causing gastroenteritis in immune competent human hosts and invasive disease as a result of the immune deficiency of HIV infections. Unpublished data (RH and JW) have shown that $S$. Typhimurium ST313 is a common cause of gastroenteritis in healthy people but also has the ability to cause septicaemia, perhaps opportunistically, in an immune deficient human host. Little sub-typing data on Salmonella from diarrhoeic stools in sub-Saharan Africa is available and it is important that we investigate how common $S$. Typhimurium ST313 is in the gut of the immune competent host: is ST313 an opportunist or a true pathogen? Although $S$. Typhimurium is now circulating in the human population there may yet prove to be an animal reservoir acting as the source for which humans were, until HIV infection expanded, the less favourable habitat, or sink [23]. If this hypothetical animal reservoir could be identified as real then the microevolution of virulence in human pathogens could be studied in detail.

Is there an animal reservoir for $\mathrm{S}$. Typhimurium ST313?

Serovars of NTS are widespread and although commonly associated with specific animals, detailed investigations in Kenya have failed to identify an animal host for the $S$. Typhimurium strain causing human invasive disease [24,25]. For $137 \quad S$. Typhimurium isolates from patients matched with isolates from the food consumed, the animals they kept, and the environment around their home, no common types were found using standard molecular methods [24]. Further studies using phage typing and pulsed-field gel electrophoresis (PFGE) showed that 104 isolates of $S$. Typhimurium from Nairobi and Kilifi in Kenya were from 11 different phage types and eight different PFGE patterns. The $S$. Typhimurium isolates from Kilifi, however, formed a cluster of mainly phage type DT56 which gave a single PFGE pattern [26]. These isolates were collected between 1994 and 1997, so they are possibly $S$. Typhimurium ST313. Although the phage type described, $S$. Typhimurium DT56, is believed to be host adapted to birds [27], the sequence type found in British birds ( $S$. Typhimurium ST568) is different from the $S$. Typhimurium DT56 associated with humans in Kenya. These studies raise the possibility of birds as a source of $S$. Typhimurium ST313 and the relationship between the $S$. Typhimurium DT56 isolates from birds and humans remains to be described but is of great interest. The importance of the detailed description of $S$. Typhimurium ST313 [20] should not be underestimated, but if the opportunities in our post genomic era are to be fully realised then this research must be translated into useful tools to reduce the burden of this dreadful disease [28]. The detailed description of the spread of $S$. Typhimurium ST313 is a major breakthrough and shows how new nucleic acid sequencing technology can be used for epidemiology of NTS infection but the expansion of $S$. 
Typhimurium ST313 only partially explains the emergence of drug resistant, invasive, NTS infection.

Other non-typhoidal serotypes of Salmonella associated with invasive human disease

Regional variation [29] and differing invasive capability [30] are associated with different serotypes and detailed epidemiology is now needed to establish the extent to which $S$. Typhimurium ST313 is replacing local strains. In South Africa, using more traditional molecular typing methods, research has shown considerable diversity in 652 isolates of invasive $S$. Typhimurium cultured from predominantly HIV-positive patients in 2006-2007 [31]. Unusual serotypes, such as Salmonella Isangi, have been associated with HIV infection, nosocomial (implying human-to-human) transmission and higher death rates [32] and in Ethiopia multiple-drug-resistant $S$. Concord was by far the most common Salmonella serotype found in the stools of 1,225 children in 2006 [33].

Has $S$. Typhimurium ST313 failed to penetrate these regions because HIV infection is not common; is it present but undetected; or is it not present because the epidemiology has not favoured it? The advantage of next generation sequencing (NGS) technology is the ability to provide information about any bacterial species - it is truly a molecular blood agar plate for modern day microbiologists. The association between
$S$. Typhimurium ST313 and invasive NTS infection is clear, and the final proof of virulence may come from laboratory experiments in animal model systems [28], but the work remains incomplete until vaccines and new diagnostics are implemented for general use in regions of the world where invasive NTS infection is endemic [28] (Table).

\section{Conclusion}

Next generation sequencing is now inexpensive, by Western standards, and wealthy countries are poised to implement the technology in real time for public health investigations [34]. The power for clinical diagnostics is also being realised [35], which raises the possibility for reference laboratories of subSaharan Africa to "leapfrog" technology currently in use in Europe. Global monitoring is in place by the World Health Organisation's Global Foodborne Infections Network [29] and new initiatives are being exploited to transform monitoring of infectious diseases by the implementation of global surveillance by NGS. This global system will link databases of clinical and epidemiological data with identification and a detailed genetic characterization of any and all microorganisms. But the question remains: how can we ensure that sub-Saharan populations also benefit from this genomic revolution?

Table. Key studies describing the emergence of Salmonella Typhimurium ST313

\begin{tabular}{|l|l|l|l|}
\hline Study & Strains collected & Conclusion & Reference \\
\hline $\begin{array}{l}\text { Comparison of human and animal } \\
\text { NTS isolates by PFGE }\end{array}$ & $\begin{array}{l}\text { Kenya } \\
1998-2000\end{array}$ & $\begin{array}{l}\text { Lack of demonstable animal } \\
\text { reservior for new strain of } S . \\
\text { Typhimiurium }\end{array}$ & 24 \\
\hline $\begin{array}{l}\text { Comparison of human and animal } \\
\text { NTS isolates by PFGE }\end{array}$ & $\begin{array}{l}\text { Kenya } \\
\text { strain likely }\end{array}$ & 25 \\
\hline $\begin{array}{l}\text { Molecular epidemiology of NTS } \\
\text { from two sites }\end{array}$ & $\begin{array}{l}\text { Kenya } \\
1994-1997\end{array}$ & $\begin{array}{l}\text { Emergence of DT56 in humans in } \\
\text { Kilifi but not in Nairobi }\end{array}$ & 26 \\
\hline $\begin{array}{l}\text { Genome sequencing of NTS } \\
\text { isolates }\end{array}$ & $\begin{array}{l}\text { Several sub-Saharan } \\
\text { countries 1977- 2010 }\end{array}$ & $\begin{array}{l}\text { Emergence of ST313 as a possible } \\
\text { human adapted strain of S. } \\
\text { Typhimurium }\end{array}$ & 20 \\
\hline $\begin{array}{l}\text { Genome sequencing of NTS } \\
\text { isolates }\end{array}$ & Malawi 1997-2006 & $\begin{array}{l}\text { Emergence of ST313 as a cause of } \\
\text { invasive disease in humans }\end{array}$ & 19 \\
\hline $\begin{array}{l}\text { Microbiological study of 301 } \\
\text { invasive NTS isolates }\end{array}$ & Zimbabwe 1994-1996 & $\begin{array}{l}\text { Early description of invasive NTS in } \\
\text { sub-Saharan Africa }\end{array}$ & 14 \\
\hline Clinical study of AIDS patients & Haiti 1983 & First report of NTS in AIDS & 9 \\
\hline $\begin{array}{l}\text { Molecular epidemiology of 652 } \\
\text { NTS isolates }\end{array}$ & South Africa 2006-7 & $\begin{array}{l}\text { Considerable diversity exists in } \\
\text { human invasive NTS in South Africa }\end{array}$ & 31 \\
\hline
\end{tabular}

NTS: Non-typhoidal Salmonella 


\section{References}

1. Feasey NA, Dougan G, Kingsley RA, Heyderman RS, Gordon MA (2012) Invasive non-typhoidal Salmonella disease: an emerging and neglected tropical disease in Africa. Lancet 379: 2489-2499.

2. Morpeth SC, Ramadhani HO, Crump JA (2009) Invasive nonTyphi Salmonella disease in Africa. Clin Infect Dis 49: 606611.

3. Hart CA, Beeching NJ, Duerden BI, Curry A, French N, Kariuki S, Graham SM, Gordon MA, Hoggard PG, Kewn S, Back DJ (2000) Infections in AIDS. J Med Microbiol 49: 947-967.

4. Kariuki S, Gilks C, Corkill J, Kimari J, Benea A, Waiyaki P, Hart CA (1996) Multi-drug resistant non-typhi Salmonellae in Kenya. J Antimicrob Chemother 38: 425-434.

5. Rubino S, Spanu L, Mannazzu M, Schiaffino A, Mura MS, Cappuccinelli P, Aceti A (1999) Molecular typing of nontyphoid Salmonella strains isolated from HIV-infected patients with recurrent salmonellosis. Aids 13: 137-139.

6. Green SD, Cheesbrough JS (1993) Salmonella bacteraemia among young children at a rural hospital in western Zaire. Ann Trop Paediatr 13: 45-53.

7. Berkley JA, Lowe BS, Mwangi I, Williams T, Bauni E, Mwarumba S, Ngetsa C, Slack MP, Njenga S, Hart CA, Maitland K, English M, Marsh K, Scott JA (2005) Bacteremia among children admitted to a rural hospital in Kenya. N Engl J Med 352: 39-47.

8. Gordon MA, Banda HT, Gondwe M, Gordon SB, Boeree MJ, Walsh AL, Corkill JE, Hart CA, Gilks CF, Molyneux ME (2002) Non-typhoidal Salmonella bacteraemia among HIVinfected Malawian adults: high mortality and frequent recrudescence. Aids 16: 1633-1641.

9. Pitchenik AE, Fischl MA, Dickinson GM, Becker DM, Fournier AM, O'Connell MT, Colton RM, Spira TJ (1983) Opportunistic infections and Kaposi's sarcoma among Haitians: evidence of a new acquired immunodeficiency state. Ann Intern Med 98: 277-284.

10. Jacobs JL, Gold JW, Murray HW, Roberts RB, Armstrong D (1985) Salmonella infections in patients with the acquired immunodeficiency syndrome. Ann Intern Med 102: 186-188.

11. Nga TV, Parry CM, Le T, Lan NP, Diep TS, Campbell JI, Hoang NV, Dung le T, Wain J, Dolecek C, Farrar JJ, Chau NV, Hien TT, Day JN, Baker S (2012) The decline of typhoid and the rise of non-typhoid Salmonellae and fungal infections in a changing HIV landscape: bloodstream infection trends over 15 years in southern Vietnam. Trans R Soc Trop Med Hyg 106: 26-34.

12. Feasey NA, Archer BN, Heyderman RS, Sooka A, Dennis B, Gordon MA, Keddy KH (2010) Typhoid fever and invasive nontyphoid salmonellosis, Malawi and South Africa. Emerg Infect Dis 16: 1448-1451.

13. Reddy EA, Shaw AV, Crump JA (2010) Community-acquired bloodstream infections in Africa: a systematic review and meta-analysis. Lancet Infect Dis 10: 417-432.

14. Rubino S, Gabrielli A, Rwende A, Gwanzura L, Cappuccinelli P (1998) Salmonella and AIDS: an emerging problem. Cntr Afr J Med 44: 83-84.

15. Kruger T, Szabo D, Keddy KH, Deeley K, Marsh JW, Hujer AM, Bonomo RA, Paterson DL (2004) Infections with nontyphoidal Salmonella species producing TEM-63 or a novel TEM enzyme, TEM-131, in South Africa. Antimicrob Agents Chemother 48: 4263-4270.
16. Govender N, Smith AM, Karstaedt AS, Keddy KH (2009) Plasmid-mediated quinolone resistance in Salmonella from South Africa. J Med Microbiol 58: 1393-1394.

17. Kariuki S, Gilks C, Kimari J, Muyodi J, Waiyaki P, Hart CA (1999) Analysis of Salmonella enterica serotype Typhimurium by phage typing, antimicrobial susceptibility and pulsed-field gel electrophoresis. J Med Microbiol 48: 1037-1042.

18. Msefula CL, Kingsley RA, Gordon MA, Molyneux E, Molyneux ME, MacLennan CA, Dougan G, Heyderman RS (2012) Genotypic homogeneity of multidrug resistant $S$. Typhimurium infecting distinct adult and childhood susceptibility groups in Blantyre, Malawi. PLoS One 7: e42085.

19. Kingsley RA, Msefula CL, Thomson NR, Kariuki S, Holt KE, Gordon MA, Harris D, Clarke L, Whitehead S, Sangal V, Marsh K, Achtman M, Molyneux ME, Cormican M, Parkhill J, MacLennan CA, Heyderman RS, Dougan G (2009) Epidemic multiple drug resistant Salmonella Typhimurium causing invasive disease in sub-Saharan Africa have a distinct genotype. Genome Res 19: 2279-2287.

20. Okoro CK, Kingsley RA, Connor TR, Harris SR, Parry CM, Al-Mashhadani MN, Kariuki S, Msefula CL, Gordon MA, de Pinna E, Wain J, Heyderman RS, Obaro S, Alonso PL, Mandomando I, Maclennan CA, Tapia MD, Levine MM, Tennant SM, Parkhill J, Dougan G (2012) Intracontinental spread of human invasive Salmonella Typhimurium pathovariants in sub-Saharan Africa. Nat Genet doi:10.1038/ng.2423.

21. Boor KJ (2006) Bacterial stress responses: what doesn't kill them can make then stronger. PLoS Biol 4: e23.

22. Holt KE, Thomson NR, Wain J, Langridge GC, Hasan R, Bhutta ZA, Quail MA, Norbertczak H, Walker D, Simmonds M, White B, Bason N, Mungall K, Dougan G, Parkhill J (2009) Pseudogene accumulation in the evolutionary histories of Salmonella enterica serovars Paratyphi A and Typhi. BMC Genomics 10: 36.

23. Sokurenko EV, Gomulkiewicz R, Dykhuizen DE (2006) Source-sink dynamics of virulence evolution. Nat Rev Microbiol 4: 548-555.

24. Kariuki S, Revathi G, Gakuya F, Yamo V, Muyodi J, Hart CA (2002) Lack of clonal relationship between non-typhi Salmonella strain types from humans and those isolated from animals living in close contact. FEMS Immunol Med Microbiol 33: 165-171.

25. Kariuki S, Revathi G, Kariuki N, Kiiru J, Mwituria J, Muyodi J, Githinji JW, Kagendo D, Munyalo A, Hart CA (2006) Invasive multidrug-resistant non-typhoidal Salmonella infections in Africa: zoonotic or anthroponotic transmission? J Med Microbiol 55: 585-591.

26. Kariuki S, Oundo JO, Muyodi J, Lowe B, Threlfall EJ, Hart CA (2000) Genotypes of multidrug-resistant Salmonella enterica serotype typhimurium from two regions of Kenya. FEMS Immunol Med Microbiol 29: 9-13.

27. Hughes LA, Wigley P, Bennett M, Chantrey J, Williams N (2010) Multi-locus sequence typing of Salmonella enterica serovar Typhimurium isolates from wild birds in northern England suggests host-adapted strain. Lett Appl Microbiol 51: 477-479.

28. Okeke IN and Wain J (2008) Post-genomic challenges for collaborative research in infectious diseases. Nat Rev Microbiol 6: 858-864. 
29. Hendriksen RS, Vieira AR, Karlsmose S, Lo Fo Wong DM, Jensen AB, Wegener HC, Aarestrup FM (2011) Global monitoring of Salmonella serovar distribution from the World Health Organization Global Foodborne Infections Network Country Data Bank: results of quality assured laboratories from 2001 to 2007. Foodborne Pathog Dis 8: 887-900.

30. Langridge GC, Nair S, Wain J (2009) Nontyphoidal Salmonella serovars cause different degrees of invasive disease globally. J Infect Dis 199: 602-603.

31. Keddy KH, Dwarika S, Crowther P, Perovic O, Wadula J, Hoosen A, Sooka A, Crewe-Brown HH, Smith AM (2009) Genotypic and demographic characterization of invasive isolates of Salmonella Typhimurium in HIV co-infected patients in South Africa. J Infect Dev Ctries 3: 585-592.

32. Wadula J, von Gottberg A, Kilner D, de Jong G, Cohen C, Khoosal M, Keddy K, Crewe-Brown H (2006) Nosocomial outbreak of extended-spectrum beta-lactamase-producing Salmonella isangi in pediatric wards. Pediatr Infect Dis J 25: 843-844.

33. Beyene G, Nair S, Asrat D, Mengistu Y, Engers H, Wain J (2011) Multidrug resistant Salmonella Concord is a major cause of salmonellosis in children in Ethiopia. J Infect Dev Ctries 5: 23-33.

34. Loman NJ, Misra RV, Dallman TJ, Constantinidou C, Gharbia SE, Wain J, Pallen MJ (2012) Performance comparison of benchtop high-throughput sequencing platforms. Nat Biotechnol 30: 434-439.

35. Didelot $\mathrm{X}$, Bowden R, Wilson DJ, Peto TE, Crook DW (2012) Transforming clinical microbiology with bacterial genome sequencing. Nat Rev Genet 13: 601-612.

\author{
Corresponding author \\ John Wain \\ NRP Innovation Centre \\ Norwich Research Park \\ Colney Lane, Norwich, Norfolk, NR4 7GJ \\ United Kingdom \\ Telephone: + 441603597567 \\ Email: j.wain@uea.ac.uk
}

Conflict of interests: No conflict of interests is declared. 